\title{
Direitos constitucionais e povos indígenas: apontamentos sobre a disputa pela efetivação do direito fundamental às suas terras tradicionais
}

\author{
Constitutional rights and indigenous peoples: remarks on \\ the dispute of effecting the basic law to their traditional \\ lands
}

\author{
Antônio Hilário Aguilera Urquiza ${ }^{1}$ \\ Anderson Santos ${ }^{2}$
}

DOI: http://dx.doi.org/10.20435/tellus.v0i42.680

\begin{abstract}
Resumo: O presente trabalho tem por objetivo analisar os direitos fundamentais dos povos indígenas conquistados com a promulgação da Constituição Federal de 1988, seguindo a ordem internacional de proteção de Direitos Humanos e o rompimento de paradigmas inaugurados pela Convenção 169 da Organização Internacional do Trabalho (OIT). Com efeito, as efetivações dos direitos indígenas perpassam várias nuances, não sendo possível aqui abordálas por completo. Assim, este trabalho se restringirá a analisar as disputas políticas que envolvem a organização do Estado brasileiro, protagonizadas por interesses de setores anti-indígenas, conforme consta no relatório do Conselho Indigenista Missionário (Cimi) de 2018, que visam, especificamente, em relação aos arts. 231 e 232 da Constituição Federal de 1988, à extinção e/ ou modificação de direitos no texto constitucional. Trata-se de pesquisa com enfoque sociojurídico, com método indutivo, com base na análise de dados, pesquisa bibliográfica, sítios da rede mundial de computadores, relatórios de organizações e produções científicas.
\end{abstract}

Palavras-chave: direitos humanos; constitucionalismo; direito indígena; demarcação.

\begin{abstract}
This paper aims to analyze the fundamental rights of indigenous peoples conquered with the promulgation of the Federal Constitution of 1988, following the international order of protection of Human Rights and the breaking of paradigms inaugurated by Convention 169 of the International Labor Organization (ILO). Indeed, the realization of indigenous rights permeates
\end{abstract}

1 Universidade Católica Dom Bosco (UCDB), Campo Grande, Mato Grosso do Sul, Brasil.

2 Universidade Federal de Mato Grosso do Sul (UFMS), Campo Grande, Mato Grosso do Sul, Brasil. 
various nuances, and it is not possible here to address them completely. Thus, this paper will be restricted to analyzing the political disputes involving the organization of the Brazilian State, carried out by interests of anti-indigenous sectors, as stated in the report of the Indigenous Missionary Council (Cimi) of 2018, which aimed, specifically, in relation to arts. 231 and 232 of the Federal Constitution of 1988, at the extinction and/or modification of rights in the constitutional text. This is a research with a socio-legal focus, with the inductive method, based on data analysis, bibliographic research, sites of World Wide Web, organization reports, and scientific productions.

Keywords: human rights; constitutionalism; indigenous law; demarcation.

\section{INTRODUÇÃO}

A presente pesquisa, de caráter empírico, realizada a partir do acúmulo de experiência junto à advocacia popular, surgiu após provocações feitas por participantes de uma oficina ministrada na cidade de Alta Floresta, MT, em fevereiro de 2019, pois foi considerado um tema atual e de suma importância para as comunidades indígenas. Dessa forma, os esforços foram a fim de reunir todas as informações pertinentes ao tema em um artigo científico para utilização como instrumento de formação de jovens e anciões, lideranças dos povos indígenas em âmbito nacional, resultando neste trabalho. Assim, a pesquisa tem esse cunho de importância, busca levar o diálogo acadêmico-científico entre as aldeias e os espaços de discussão acerca dos direitos indígenas no país.

Feitas essas considerações, busca-se traçar uma linha histórica, a fim de abordar o período pré-constituinte e a promulgação da Constituição Federal de 1988, fazendo uma análise entre os direitos indígenas antes e após o ano de 1988, à luz de sua efetivação e desafios de ordem política, econômica, ideológica e social.

Antes da promulgação da Constituição Federal, em 5 de outubro de 1988, os povos indígenas tinham aparatos jurídicos que garantiam, apenas, a ocupação permanente ${ }^{3}$ de seus territórios tradicionais. Podemos notar que essas constituições

3 Constituição Federal de 1934: "Art. 129. Será respeitada a posse de terras de silvícolas que nelas se achem permanentemente localizados, sendo-lhes, no entanto, vedado aliená-las"; Constituição Federal de 1937: "Art. 154. Será respeitada aos silvícolas a posse das terras em que achem localizados em caráter permanente, sendo-lhes, porém, vedada sua alienação das mesmas"; Constituição Federal de 1946: "Art. 216. Será respeitada aos silvícolas a posse das terras onde se achem permanentemente localizados, com a condição de não a transferirem"; Constituição Federal de 1967 - Emenda Constitucional n. 1 de 1969: "Art. 198- As terras habi- 
não priorizavam a reprodução sociocultural dos povos indígenas, muito menos a possibilidade de demarcação dos territórios reivindicados por essas comunidades.

Vale destacar o primordial empenho e articulação do movimento indígena nacional a fim de reivindicar na pré-constituinte (1986-87) a promulgação dos artigos constitucionais referentes aos direitos indígenas. Apoiado por ONGs, movimentos sociais e sociedade civil, redigiu e buscou a aprovação dos arts. 231 e 232 da Carta Magna, o que se dá maior ênfase.

Após a aprovação do texto constitucional, incorporando o capítulo "Dos Índios", inaugurou-se um novo cenário da política de Estado, seguindo uma tendência internacional de proteção dos Direitos Humanos e reconhecendo a existência de uma sociedade heterogênea (DUPRAT, 2014), voltada aos povos tradicionais de nosso país.

\section{CONSTITUIÇÃO FEDERAL DE 1988}

Seguindo a tendência de reconhecimento de grupos distintos dentro do Estado, a Lei Maior deixou de somente reconhecer o direito indígena ao território, mas também trouxe em seu texto uma inovação quanto às garantias de outros direitos dos indígenas, nos artigos 231 e 232, que compõem o Capítulo VIII da Constituição, veja:

Art. 231. São reconhecidos aos índios sua organização social, costumes, línguas, crenças e tradições, e os direitos originários sobre as terras que tradicionalmente ocupam, competindo à União demarcá-las, proteger e fazer respeitar todos os seus bens.

$\S 1$ 으o ão terras tradicionalmente ocupadas pelos índios as por eles habitadas em caráter permanente, as utilizadas para suas atividades produtivas, as imprescindíveis à preservação dos recursos ambientais necessários a seu bem-estar e as necessárias a sua reprodução física e cultural, segundo seus usos, costumes e tradições.

$\S 20$ As terras tradicionalmente ocupadas pelos índios destinam-se a sua posse permanente, cabendo-lhes o usufruto exclusivo das riquezas do solo, dos rios e dos lagos nelas existentes.

tadas pelos silvícolas são inalienáveis nos termos que a lei federal determinar, a eles cabendo a sua posse permanente e ficando reconhecido o seu direito ao usufruto exclusivo das riquezas naturais e de todas as utilizadas nelas existentes. 1ㅇ- Ficam declaradas a nulidade e a extinção dos efeitos jurídicos de qualquer natureza que tenham por objeto o domínio, a posse ou a ocupação de terras habitadas pelos silvícolas". 
$\S 3$ O O aproveitamento dos recursos hídricos, incluídos os potenciais energéticos, a pesquisa e a lavra das riquezas minerais em terras indígenas só podem ser efetivados com autorização do Congresso Nacional, ouvidas as comunidades afetadas, ficando-lhes assegurada participação nos resultados da lavra, na forma da lei.

$\S 4$ ㅇ As terras de que trata este artigo são inalienáveis e indisponíveis, e os direitos sobre elas, imprescritíveis.

$\S 5$ ํ É vedada a remoção dos grupos indígenas de suas terras, salvo, "ad referendum" do Congresso Nacional, em caso de catástrofe ou epidemia que ponha em risco sua população, ou no interesse da soberania do País, após deliberação do Congresso Nacional, garantido, em qualquer hipótese, o retorno imediato logo que cesse o risco.

$\S 60$ São nulos e extintos, não produzindo efeitos jurídicos, os atos que tenham por objeto a ocupação, o domínio e a posse das terras a que se refere este artigo, ou a exploração das riquezas naturais do solo, dos rios e dos lagos nelas existentes, ressalvado relevante interesse público da União, segundo o que dispuser lei complementar, não gerando a nulidade e a extinção direito a indenização ou a ações contra a União, salvo, na forma da lei, quanto às benfeitorias derivadas da ocupação de boa-fé.

$\S 7$ ㅇ Não se aplica às terras indígenas o disposto no art. 174, § 3 o e $\S 4 ㅇ$.

Art. 232. Os índios, suas comunidades e organizações são partes legítimas para ingressar em juízo em defesa de seus direitos e interesses, intervindo o Ministério Público em todos os atos do processo. (BRASIL, 1988).

O capítulo VIII da Constituição Federal de 1988 se assemelha a uma constituição dos direitos indígenas, reconhecendo "sua organização social, costumes, línguas, crenças e tradições", além dos "direitos originários sobre as terras que tradicionalmente ocupam", formando-se como uma norma superior aplicada a todas as comunidades indígenas existentes no Brasil, mesmo com traços culturais, tradições e costumes totalmente diferenciados.

O Supremo Tribunal Federal, quando do julgamento do caso Raposa Serra do Sol, levanta aspectos de importante relevância quanto aos direitos indígenas presentes na Carta Maior, promulgada em 1988.

O Supremo Tribunal Federal, por ocasião do julgamento da Pet. 3388, caso Raposa Serra do Sol, acentuou que: EMENTA*: AÇÃO POPULAR.

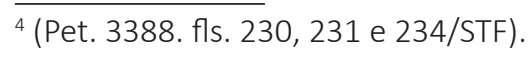


DEMARCAÇÃO DA TERRA INDÍGENA RAPOSA SERRA DO SOL. INEXISTÊNCIA DE VÍCIOS NO PROCESSO ADMINISTRATIVO-DEMARCATÓRIO. OBSERVÂNCIA DOS ARTS. 231 E 232 DA CONSTITUIÇÃO FEDERAL, BEM COMO DA LEI N. 6.001/73 E SEUS DECRETOS REGULAMENTARES.

CONSTITUCIONALIDADE E LEGALIDADE DA PORTARIA N. 534/2005, DO MINISTRO DA JUSTIÇA, ASSIM COMO DO DECRETO PRESIDENCIAL HOMOLOGATÓRIO. RECONHECENDO DA CONDIÇÃO INDÍGENA DA ÁREA DEMARCADA, EM SUA TOTALIDADE. MODELO CONTÍNUO DE DEMARCAÇÃO. CONSTITUCIONALIDADE. REVELAÇÃO DO REGIME CONSTITUCIONAL DE DEMARCAÇÃO DAS TERRAS INDÍGENAS. A CONSTITUIÇÃO FEDERAL COMO ESTATUTO JURÍDICO DA CAUSA INDÍGENA. A DEMARCAÇÃO DAS TERRAS INDÍGENAS COMO CAPÍTULO AVANÇADO DO CONSTITUCIONALISMO FRATERNAL. INCLUSÃO COMUNITÁRIA PELA VIA DA IDENTIDADE ÉTNICA. VOTO DO RELATOR QUE FAZ AGREGAR AOS RESPECTIVOS FUNDAMENTOS SALVAGUARDAS INSTITUCIONAIS DITADAS PELA SUPERLATIVA IMPORTÂNCIA HISTÓRICO-CULTURAL DA CAUSA. SALVAGUARDAS AMPLIADAS A PARTIR DE VOTO-VISTA DO MINISTRO MENEZES DIREITO E DESLOCADAS PARA A PARTE DISPOSITIVA DA DECISÃO.

\section{$[\ldots]$}

9. A demarcação de terras indígenas como capítulo avançado do constitucionalismo fraternal. Os arts. 231 e 232 da Constituição Federal são de finalidade nitidamente fraternal ou solidária, própria de uma quadra constitucional que se volta para efetivação de um novo tipo de igualdade: a igualdade civil-moral de minorias, tendo em vista o proto-valor da integração comunitária. Era constitucional compensatória de desvantagens historicamente acumuladas, a se viabilizar por mecanismos oficiais de ações afirmativas. No caso, os índios a desfrutar de um espaço fundiário que Ihes assegure meios dignos de subsistência econômica para mais eficazmente poderem preservar sua identidade somática, linguística e cultural. Processo de uma aculturação que não se dilui no convívio com os não-índios, pois a aculturação de que trata a Constituição não é a perda de identidade étnica, mas somatório de mundividências. Uma soma, e não uma subtração. Ganho, e não perda. Relações interétnicas de mútuo proveito, a caracterizar ganhos culturais incessantemente cumulativos. Concretização constitucional do valor de inclusão comunitária pela via de identidade étnica.

Todas as organizações sociais, culturas, costumes, tradições, línguas e crenças foram reconhecidos no texto constitucional, não de forma declaratória, mas sim recepcionados, cabendo ao Estado brasileiro fazer respeitar essas 
diferenças socioculturais, que ainda têm embasamento jurídico no preâmbulo ${ }^{5}$ da Constituição, quando esta traz que a sociedade brasileira é pluralista, e no art. 4ํㅡ, III, que afirma a autodeterminação dos povos.

Com efeito, os povos indígenas possuem uma diversidade de direito, tanto cultural, organizacional, quanto às terras tradicionais, podendo exercê-los conforme seus costumes e tradições.

O Supremo Tribunal Federal trata os direitos dos povos indígenas, na Constituição Federal, como um estatuto jurídico da causa indígena ${ }^{7}$, isto é, ao nosso modo de ver, uma constituição do direito indígena ancorada na Carta Magna, sendo, de fato, um avanço dentro do constitucionalismo brasileiro.

A terra tradicionalmente ${ }^{8}$ ocupada pelos povos indígenas é devidamente compreendida como o complexo capaz de garantir, primeiramente, o espaço habitado em caráter permanente, áreas de coleta, pesca e caça, com a devida preservação dos recursos ambientais necessários ao bem-estar da comunidade ao longo dos tempos, e capaz de garantir a reprodução física e cultural dessas populações, geração após geração, de acordo com sua organização social, costumes, tradições e crenças.

Nossa Constituição ainda traz importantes aspectos em relação ao uso da terra pelos povos originários, o qual se diferencia da posse da terra pelo não

\footnotetext{
5 "Nós, representantes do povo brasileiro, reunidos em Assembleia Nacional Constituinte para instituir um Estado Democrático, destinado a assegurar o exercício dos direitos sociais e individuais, a liberdade, a segurança, o bem-estar, o desenvolvimento, a igualdade e a justiça como valores supremos de uma sociedade fraterna, pluralista e sem preconceitos, fundada na harmonia social e comprometida, na ordem interna e internacional, com a solução pacífica das controvérsias, promulgamos, sob a proteção de Deus, a seguinte CONSTITUIÇÃO DA REPÚBLICA FEDERATIVA DO BRASIL."

6 "Art. 40 A República Federativa do Brasil rege-se nas suas relações internacionais pelos seguintes princípios: [...] III - autodeterminação dos povos;"

7 Pet. 3388/STF.

8 O tradicionalmente refere-se não a uma circunstância temporal, mas ao modo tradicional de os índios ocuparem e utilizarem as terras e ao modo tradicional de produção, enfim, ao modo tradicional de como eles se relacionam com a terra, já que há comunidades mais estáveis, e as que têm espaços mais amplos pelo qual se deslocam etc. Daí dizer- se que tudo se realiza, segundo seus usos, costumes e tradições (SILVA, 2005, p. 836).
} 
índio, advinda do direito de propriedade civilista ${ }^{9}$, que é o indigenato ${ }^{10}$. 0 texto constitucional não deu a propriedade da terra às comunidades indígenas, mas somente a posse e o usufruto exclusivo das riquezas do solo, dos rios e dos lagos nelas existentes, o que está previsto no parágrafo 20 do art. 231, significando que a Constituição salvaguarda o direito comunitário dos índios diante do modelo individualista da sociedade não índia.

Para Eloy Amado (2014, p. 73), a “[...] posse indígena não pode ser tratada da mesma forma que a posse regulada pelo direito civil brasileiro, isso porque sua previsão decorre de comando constitucional", então, podemos verificar aqui uma distinção jurídica entre a posse meramente civilista e a posse constitucional indígena, sendo que a primeira é baseada no direito de propriedade, individualista e exploratória, e a segunda, baseada em um direito coletivo, de uma comunidade, para sua subsistência e a exploração dos recursos existentes calcada em costumes, crenças e tradições com respeito ao meio ambiente, para garantia da reprodução física e cultural, isto é, foge à lógica capitalista de exploração da terra e dos recursos nela existentes. Pode-se afirmar que a posse indígena, advinda do comando constitucional, é superior à posse civilista.

O texto constitucional traz disposições sobre o aproveitamento de "hídricos, incluídos os potenciais energéticos, a pesquisa e a lavra das riquezas minerais em terras indígenas" ( $§ 30$ do art. 231), além de tratar da indisponibilidade, inalienação e imprescritibilidade das terras indígenas em seu $\S 4$, vedar a remoção de povos, salvo "ad referendum" do Congresso Nacional, finalizando com a nulidade e extinção de títulos que tenham "por objeto a ocupação, o domínio e a posse das terras a que se refere este artigo, ou a exploração das riquezas naturais do solo, dos rios e dos lagos nelas existentes", no $§ 60$.

Temos então o art. 232, que rompe com o regime tutelar imposto aos povos indígenas ao garantir que "os índios, suas comunidades e organizações são partes legítimas para ingressar em juízo em defesa de seus direitos e interesses"; em

9 Art. 1.196, CC - "Considera-se possuidor todo aquele que tem de fato o exercício, pleno ou não, de algum dos poderes inerentes à propriedade".

"Art. 1.228. O proprietário tem a faculdade de usar, gozar e dispor da coisa, e o direito de reavê-la do poder de quem quer que injustamente a possua ou detenha".

${ }^{10}$ Por conseguinte, o indigenato não é um fato dependente de legitimação, ao passo que a ocupação, como fato posterior, depende de requisitos que a legitimem (MENDES JÚNIOR, 1912, p. 58). 
interpretação lato sensu, se os índios têm legitimidade para ingressar em juízo, podem eles gerir os atos da vida civil, estando então equiparados à capacidade regulada na lei adstrita ao não índio.

Em 1996, o então presidente da República, Fernando Henrique Cardoso, editou o Decreto n. 1.775/96 (BRASIL, 1996), que passaria a disciplinar administrativamente a demarcação de terras indígenas. Cuidaremos de compreendê-lo no tópico seguinte.

\section{DECRETO 1.775, DE 8 DE JANEIRO DE 1996}

O Decreto 1.775/96 foi criado para dar corpo a um procedimento administrativo de demarcação de terras indígenas no país, ainda não existente, provocado pela formulação da tese de que as demarcação de terras indígenas não obedecia ao princípio do contraditório e da ampla defesa, conforme acreditavam os representantes dos setores que se contrapunham ao método adotado pela Constituição Federal para a efetivação do direito ao território indígena; para isso, o decreto incorporou nove fases procedimentais, por nós compreendidas da seguinte forma:

1. Reivindicação pela comunidade indígena da demarcação de sua terra tradicional11;

2. Publicação de Portaria de Constituição de Grupo Técnico (GT) - Cabe ao presidente da Fundação Nacional do Índio (Funai) publicar, no Diário Oficial da União, portaria constituindo grupo técnico, coordenado por antropólogo com qualificação reconhecida em relação ao povo e à terra indígena (TI) a ser demarcada, podendo contar com outros profissionais para "realizar estudos complementares de natureza etno-histórica, sociológica, jurídica, cartográfica, ambiental e o levantamento fundiário necessários à delimitação"12;

3. Envio do Relatório Circunstanciado de Identificação e Delimitação ao Presidente

\footnotetext{
${ }^{11}$ Pontua que essa fase não se encontra no texto do decreto, todavia, como a Funai não opera ex officio, ou seja, não havendo a provocação da comunidade, não se inicia o procedimento administrativo, então essa se configura como uma fase extrínseca ao decreto.

12 Art. 2, "§ 1 ㅇ O órgão federal de assistência ao índio designará grupo técnico especializado, composto preferencialmente por servidores do próprio quadro funcional, coordenado por antropólogo, com a finalidade de realizar estudos complementares de natureza etno-histórica, sociológica, jurídica, cartográfica, ambiental e o levantamento fundiário necessários à delimitação".
} 
Direitos constitucionais e povos indígenas: apontamentos sobre a disputa pela efetivação do direito fundamental às suas terras tradicionais

da Funai - Feito o estudo de identificação e delimitação, o grupo técnico apresentará Relatório Circunstanciado de Identificação e Delimitação (Recid) ao presidente do órgão federal de assistência ao índio, "caracterizando a terra indígena a ser demarcada", conforme o § 6ํ13 do Dec. 1.775/96;

4. Publicação do Relatório Circunstanciado de Identificação e Delimitação - De porte do Recid, caberá ao presidente do órgão de assistência ao índio publicar o relatório no Diário Oficial da União, onde se localiza a área de objeto de demarcação, "acompanhado de memorial descritivo e mapa da área, devendo a publicação ser afixada na sede da Prefeitura Municipal da situação do imóvel", no prazo de 15 dias;

5. Contestação e levantamento de benfeitorias - O início da contestação ao processo administrativo promovido pelo órgão indigenista oficial se dá desde a publicação da portaria de constituição do grupo técnico, até 90 (noventa) dias após a publicação do Relatório Circunstanciado de Demarcação e Delimitação (Recid), conforme preconiza o art. $2, \S 8^{0^{14}}$ do decreto. Cabe destaque de que, nesta fase, também se dá o levantamento de benfeitorias de boa-fé as quais o ocupante não indígena tem direito de indenização;

6. Envio do procedimento ao ministro de Estado da Justiça - Feito isso, nos 60 (sessenta) dias para o encerramento do prazo de contestação, cabe ao órgão indigenista oficial encaminhar ao ministro da Justiça o procedimento com "pareceres relativos às razões e provas apresentadas", como trata o parágrafo 9o15;

13 “§ 60 Concluídos os trabalhos de identificação e delimitação, o grupo técnico apresentará relatório circunstanciado ao órgão federal de assistência ao índio, caracterizando a terra indígena a ser demarcada."

14 "§ 70 Aprovado o relatório pelo titular do órgão federal de assistência ao índio, este fará publicar, no prazo de quinze dias contados da data que o receber, resumo do mesmo no Diário Oficial da União e no Diário Oficial da unidade federada onde se localizar a área sob demarcação, acompanhado de memorial descritivo e mapa da área, devendo a publicação ser afixada na sede da Prefeitura Municipal da situação do imóvel."

"§ 8ㅇ Desde o início do procedimento demarcatório até noventa dias após a publicação de que trata o parágrafo anterior, poderão os Estados e municípios em que se localize a área sob demarcação e demais interessados manifestar-se, apresentando ao órgão federal de assistência ao índio razões instruídas com todas as provas pertinentes, tais como títulos dominiais, laudos periciais, pareceres, declarações de testemunhas, fotografias e mapas, para o fim de pleitear indenização ou para demonstrar vícios, totais ou parciais, do relatório de que trata o parágrafo anterior."

15 “§ 9o Nos sessenta dias subsequentes ao encerramento do prazo de que trata o parágrafo ante- 
7. Declaração dos limites e determinação de demarcação física - De porte do procedimento, cabe ao ministro da Justiça: declarar os limites da terra indígena e determinar a sua demarcação; devolver os autos à Funai, prescrevendo diligências que julgue necessárias a fim de complementar o estudo de identificação e delimitação, que deveria ser realizado pelo órgão indigenista no prazo de noventa dias; ou, mediante decisão fundamentada, desaprovar a identificação e a devolver ao órgão de assistência ao índio para arquivamento; tais decisões deverão se dar em até trinta dias, reza o parágrafo $10^{\circ}{ }^{16}$ do art. 2ㅇ․ Cabe destaque nesse ponto à declaração dos limites que, consequentemente, levará aos atos procedimentais seguintes.

8. Homologação da Terra Indígena - Transcorridos esses atos disciplinados pelo ato normativo mencionado, a terra indígena demarcada será homologada por decreto do presidente da República, em acordo com o art. 517;

9. Registros - Finalmente, será necessário ainda, em até trinta dias após o ato anterior, promover "o respectivo registro em cartório imobiliário da comarca correspondente e na Secretaria do Patrimônio da União do Ministério da Fazenda", sendo de competência do órgão de assistência ao índio, nos dizeres do art. 6.

A Constituição Federal de 1988 determinou o prazo de 5 anos $^{18}$ para demarcação dos territórios indígenas, que expirou em 1993, sem que fossem concluídos todos os processos de demarcação devido ao acirramento da disputa entre interesses antagônicos envolvidos na questão.

rior, o órgão federal de assistência ao índio encaminhará o respectivo procedimento ao ministro de Estado da Justiça, juntamente de pareceres relativos às razões e provas apresentadas."

16 "§ 10 o Em até trinta dias após o recebimento do procedimento, o Ministro de Estado da Justiça decidirá:

I- declarando, mediante portaria, os limites da terra indígena e determinando a sua demarcação; II- prescrevendo todas as diligências que julgue necessárias, as quais deverão ser cumpridas no prazo de noventa dias;

III- desaprovando a identificação e retornando os autos ao órgão federal de assistência ao índio, mediante decisão fundamentada, circunscrita ao não atendimento do disposto no $§ 1$ 잉 do art. 231 da Constituição e demais disposições pertinentes."

17 "Art. $5^{\circ}$ A demarcação das terras indígenas, obedecido o procedimento administrativo deste Decreto, será homologada mediante decreto."

${ }^{18}$ Art. 67, ADCT, CF88. 
Tal fato é constatado pela simples análise das áreas em demarcação em Mato Grosso do Sul em relação à região norte do país. Naquelas existem terras até hoje sem criação de Grupo de Trabalho para identificação e delimitação, a exemplo da TI Nioaque, localizada no município de Nioaque; TI Kinikinau, localizada no município de Miranda; e diversos Tekoha ${ }^{19}$ Guarani e Kaiowá ao sul do Estado. Por outro lado, as terras indígenas demandadas na região norte do país foram, em quase sua integralidade, efetivamente demarcadas.

Em Mato Grosso do Sul, sul da Bahia e Região Sul, o hoje chamado "agronegócio" foi o setor que mais combateu e investiu em mecanismos para impossibilitar a efetivação do direito do índio ao seu território. Isso fez com que o então presidente editasse o Decreto n. 1.775/96, que inicialmente foi combatido pelo movimento indígena e seus aliados, mas atualmente passou a ser defendido.

Para poder compreender os trâmites que um procedimento administrativo de demarcação de terras precisa seguir até sua homologação, faz-se necessário compreender como o Estado brasileiro está organizado em suas esferas de poder e atribuições, refletindo como esses poderes podem influenciar positiva ou negativamente na efetivação do direito indígena, aqui tratado, especificamente, o direito à terra tradicional.

\section{ORGANIZAÇÃO DO ESTADO BRASILEIRO}

Após a análise dos direitos dos índios com enfoque na demarcação de suas terras tradicionais, o principal elemento deste trabalho será apontar os principais entraves para a efetivação dos direitos fundamentais de solidariedade "[...] porque têm, ao mesmo tempo, uma dimensão 'individual' e uma dimensão 'coletiva', uma vez que concernem à pessoa humana: o índio como tal, assim como as coletividades humanas: as comunidades indígenas" (SILVA, 2016, p. 5), para a efetivação do índio à demarcação de sua terra tradicionalmente ocupada.

\footnotetext{
${ }_{19}$ Pela tradução livre, significa "lugar onde se é". Trata-se de um termo de ampla significação para os Guarani (Kaiowá e Ñandeva), é muito utilizado pelo grupo como aquele lugar onde se pode viver bem, ou onde o teko porã (o bom modo de viver) é possível. Refere-se à dimensão territorial, sendo o lugar (território) onde se desenrolam as relações sociais, políticas, culturais e simbólicas. Sobre este termo é possível obter mais informações consultando a tese de doutorado do antropólogo Levi Pereira (2004).
} 
O Estado brasileiro tem sua organização político-administrativa de forma descentralizada, e a União Federal ${ }^{20}$ é a junção dos poderes Legislativo, Executivo e Judiciário - a eles cabe trabalhar de forma independente e harmônica entre si. Sendo assim, o Estado brasileiro é formado pela União, estados, municípios, territórios e o Distrito Federal, todos com diversas competências e estruturas independentes de organização, disciplinados pela Constituição Federal.

Em relação aos Estados Federados, o professor José Afonso da Silva assevera que:

A União ficou ainda bem aquinhoada na partilha das competências federativas. Dispõe de competência material exclusiva conforme ampla enumeração de assuntos no art. 21, de competência legislativa privativa consoante discriminação constante do art. 22, de competência comum com Estados, Distrito Federal e Municípios arrolada no art. 23 e, ainda de competência legislativa concorrente com Estados sobre temas específicos no art. 24. (SILVA, 2005, p. 496).

Nesta separação de competência, vale destacar que compete à União demarcar as terras indígenas, sendo assim, não é uma mera competência, mas se trata de um direito fundamental (SILVA, 2005), impondo-se como dever da União.

Cabe, neste trabalho, trazer algumas acepções político-administrativas da União Federal, analisando-se sua organização e competência em relação aos direitos indígenas. Serão abordadas as competências ${ }^{21}$ desses poderes e o seu papel político passível de influir na temática aqui discutida.

No que tange à demarcação dos territórios indígenas, segundo o art. 231, caput, compete à União demarcá-las. Cabe ainda dizer que o art. 20 da Constituição Federal dispõe que são bens da União, entre outros, "as terras tradicionalmente ocupadas pelos índios", conforme prevê o inciso XI. Sendo assim, também compete à União "proteger e fazer respeitar todos os seus bens" - trecho insculpido no caput do art. 231 do texto constitucional.

\footnotetext{
20 "A União é a entidade federal formada pela reunião das partes componentes, constituindo pessoa jurídica de Direito Público interno, autônoma em relação às unidades federadas (ela é unidade federativa, mas não é unidade federada) e a que cabe exercer as prerrogativas da soberania do Estado brasileiro" (SILVA, 2005, p. 493).

${ }^{21}$ Competências são, assim, as diversas modalidades de poder de que se servem os órgãos ou entidades estatais para realizar suas funções (SILVA, 2005, p. 496).
} 
Dessa forma, abordaremos a seguir a divisão dos poderes do Estado brasileiro, trazendo apontamentos acerca dos instrumentos utilizados por eles para inviabilizar, modificar ou extinguir direitos.

\subsection{Poder Executivo}

O Poder Executivo é responsável pela gestão político-administrativa da União e "Pode dizer-se, de modo geral, que se trata de órgão constitucional (supremo) que tem função a prática de atos de chefia de estado, de governo e de administração" (SILVA, 2005, p. 542).

O chefe da administração pública é o presidente da República, que deve ser brasileiro nato e ter 35 (trinta e cinco) anos de idade ${ }^{22}$, eleito por voto popular e com mandato de quatro anos, podendo ser reeleito por uma vez. Cabe a ele sancionar, promulgar, publicar leis, expedir decretos e regulamentos, vetar projetos de lei etc. e tem como auxiliares os ministros de Estado. Para abarcar todas as demandas constitucionais garantidoras do bem-estar social, a administração pública federal é desconcentrada entre os ministérios e, ao caso analisado, basta mencionar o Ministério da Justiça, que descentraliza a função administrativa de demarcação de terras indígenas à Funai, sendo depois responsável pela Declaração dos Limites da Terra, objeto do estudo, e por determinar a demarcação, que, quando concluída, será enviada ao presidente da República para homologação via decreto, conforme já vimos detalhadamente em tópico anterior.

Assim, percebe-se a competência que é atribuída pela Constituição ao Poder Executivo para demarcar os territórios indígenas.

No âmbito do Poder Executivo, cabe apontar que houve, nos últimos anos, mesmo sendo um governo favorável a defender os interesses das populações indígenas, algumas iniciativas que vieram para inviabilizar e paralisar os procedimentos de demarcação. Impulsionada por meio da pressão das bancadas de congressistas contrários à causa indígena, com ênfase à bancada ruralista, foi publicada a Portaria 303/2012 (BRASIL, 2012) da Advocacia-Geral da União (AGU), que orientava os advogados da União a não operarem contra a tese do marco temporal e as 19 condicionantes da Raposa Serra do Sol - PET 3.388/STF. Essa portaria foi suspensa

\footnotetext{
${ }^{22}$ Art. 14, § 2ㅇ, VI, “a”, CF88.
} 
logo em seguida de sua publicação, todavia serviu para o governo de Dilma Rousseff paralisar todos os processos de demarcação de terras indígenas no Brasil.

Por meio do "impeachment" da presidente Dilma Rousseff, seu sucessor, Michel Temer, em seu primeiro ato enquanto presidente, editou o Parecer 001/2017 da Presidência da República (PR. 2017), que também trouxe as condicionantes do Caso Raposa Terra do Sol e a tese do marco temporal, vinculando todos os advogados da União, mas também toda a administração pública federal23, a observar as diretrizes do parecer.

O caso se agrava quando há advogados da União com responsabilidade de defender judicialmente os interesses das comunidades indígenas, por meio da Procuradoria Federal Especializada (PFE), e ficam eles proibidos de fazer, se contrário ao Parecer 001/2017. Assim, o parecer, além de aplicar teses ainda não fixadas pelo STF, também retira da comunidade indígena a autonomia do seu advogado, a PFE.

Para melhor compreensão dos efeitos desse parecer, pode-se expor dois exemplos. Primeiro, o povo Kinikinau em MS, que está reivindicando a criação de Grupo Técnico de Estudo de Identificação e Delimitação de sua terra indígena; para isso, protocolizaram ofício junto à Funai em Brasília, requerendo a publicação da portaria de criação de um Grupo de Trabalho. A Funai, em resposta, enviou ordem para que servidor lotado na Coordenação Regional de Campo Grande produzisse "qualificação" quanto ao pedido do povo. Esse servidor teve o papel de visitar o povo Kinikinau, conhecer um pouco de sua história e realizar levantamentos prévios. Tais apontamentos mostram que os Kinikinau foram expulsos da região conhecida como "Agachi", localizada no município de Miranda, MS, ainda no início do século XX; dessa forma, sendo a Funai obrigada a confrontar a trajetória do povo com o Parecer 001/2017, indeferiu administrativamente o pedido da comunidade. Segundo, no ano de 2010, vários sindicatos rurais e municípios de MS ingressaram com ações judiciais contra a Funai e União visando à aplicação do marco temporal para imunizar as fazendas abrangidas por todo o município do litigante, seja o próprio município, seja o sindicato rural, além de ações propostas por sindicatos de nível estadual; grande parte dessas ações já foram julgadas improcedentes por ilegitimidade ativa, no entanto, em alguns casos, e coincidentemente ou não, o juiz decidiu citar a comunidade para responder ao processo, momento em que a comunidade indígena

${ }^{23}$ Portaria 839, de 18 de junho de 2010/AGU (BRASIL, 2010). 
procurou a Procuradoria Federal Especializada (PFE) ${ }^{24}$ atuando junto à Funai para defesa das comunidades indígenas, para que as representasse judicialmente como é rotineiro. Para a demanda apresentada, as comunidades receberam resposta de que os "procuradores estariam impedidos de advogar em favor das comunidades e se contrapondo às 19 condicionantes e ao marco temporal" 25. Isto é, caso essas comunidades não possuíssem condições de contratar advogado particular ou ter acesso de forma pro bono, correriam o risco de ter tais processos julgados à revelia.

Destaca-se, com isso, que o Parecer 001/2017 está em vigor até este momento. Já o governo atual viola a Constituição, retirando da Funai a competência de realizar o procedimento administrativo de demarcação de terras indígenas e transferindo-a para o Ministério da Agricultura, por meio da reedição da Medida Provisória 870/2019 (BRASIL, 2019a), pela Medida Provisória 886/2019 (BRASIL, 2019b). A iniciativa presidencial foi frustrada pela rejeição da proposta pelo Congresso Nacional e, posteriormente, pela Suprema Corte no julgamento da ADI 6062. Estamos diante de um contrassenso, repudiado pelas organizações indígenas.

Figura 1 - Intenções do atual governo para a não demarcação de terras indígenas

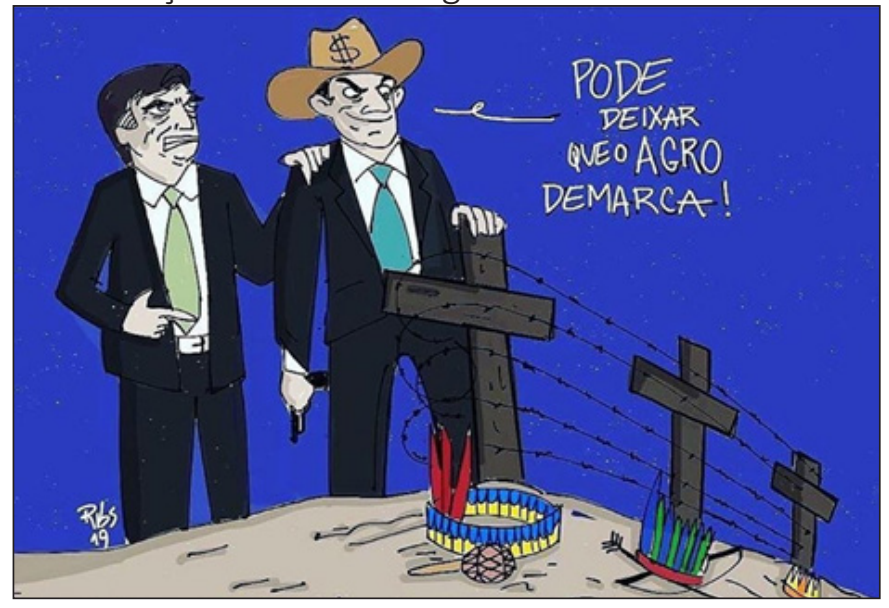

Fonte: Conselho Terena (MS), 2019.

\footnotetext{
${ }^{24}$ Regulamentado pela Portaria 839/2010/AGU (BRASIL, 2010).

${ }^{25}$ Relato feito pelo cacique Erpídio Pires, da Aldeia Potrero Guasu, em Paranhos, MS, em reunião realizada para organizar a defesa das comunidades de Arroyo Korá, Ipo'y, Potrero Guassu, Pirajuí e Sete Cerros nos autos processuais de n. 0000158-14.2010.4.03.6005, que tramitam na Justiça Federal de Ponta Porã, MS.
} 
A imagem acima é uma publicação de Conselho Terena de Mato Grosso do Sul, organização de base da Articulação dos Povos Indígenas do Brasil (Apib), após notícia da nova medida provisória que transfere a demarcação de terras indígenas para o Ministério da Agricultura ${ }^{26}$.

\subsection{Poder Legislativo}

O Poder Legislativo é composto pela união da Câmara Federal e do Senado Federal: o Congresso Nacional, que exerce suas atividades por legislaturas ${ }^{27}$, sessões legislativas ordinárias ${ }^{28}$ ou extraordinárias e reuniões ordinárias ${ }^{29}$ ou extraordinárias. Sua atribuição é legislar (art. 48), deliberar (art. 49), fiscalizar e controlar o Poder Executivo (art. 50), além de julgar crimes de responsabilidade (arts. 51, 52 e 86); por fim, tem atribuições constituintes (art. 60).

A Câmara dos Deputados é composta por representantes do povo, eleitos nos estados, nos territórios e no Distrito Federal, pautada no sistema proporcional, onde cada estado tem um número total de representantes, não podendo ser menor que oito nem maior que setenta (art. 45, § 1ㅇ).

O Senado Federal é regido pelo sistema majoritário, ao contrário da Câmara Federal, é representativo dos Estados Federados, tendo 3 (três) eleitos, com dois suplentes cada um, nos estados e no Distrito Federal. O mandato do senador é de oito anos, tendo eleições de quatro em quatro anos, quando se renovará alternadamente a composição da Casa, por um ou dois terços, conforme dispõe o art. 46.

O Conselho Indigenista Missionário, em levantamento recente, aponta que o Poder Legislativo tem várias bancadas ${ }^{30}$ formadas em razão de interesses comuns, cabendo destaque à bancada ruralista, como é popularmente conhecida, formada com 207 parlamentares e cerca de 20 senadores ligados à Frente Parlamentar

\footnotetext{
${ }^{26}$ Disponível em: https://www.instagram.com/?hl=pt-br. Acesso em: 20 jun. 2019.

${ }^{27}$ A legislatura tem duração de quatro anos e corresponde ao período que vai do início do mandato dos membros da Câmara dos Deputados até o seu término (art. 44, parágrafo único).

28 É o período anual em que deve estar reunido o Congresso para os trabalhos legislativos (SILVA, 2005, p. 517).

${ }^{29}$ Os trabalhos legislativos realizam-se efetivamente nas reuniões diárias dos congressistas, chamadas sessões ordinárias, que se processam nos dias úteis (SILVA, 2005, p. 517).

30 Termo popularmente referenciado aos grupos com interesses políticos unificados.
} 
Agropecuária; bancada da mineração, que conta com 23 deputados; bancada da bala, com 35 deputados; bancada evangélica, com 197 deputados; e a bancada das empreiteiras e construtoras, com 226 deputados (CIMI, 2018a).

Com a formação dessas bancadas, financiadas por empresários e/ou pessoas de vasto poder econômico, iniciou-se então na última década um sistemático ataque aos direitos indígenas, pois o que se entende é que, para eliminar de vez a demarcação das terras, deveria ser modificada a Constituição Federal, configurada num arcabouço jurídico altamente avançado, garantidor dos direitos dos povos tradicionais.

Merece apontamento o fenômeno de resistência indígena ${ }^{31}$, ou seja, a "retomada" de territórios que de lá foram expropriados. Esse fator incomoda, e muito, esses setores organizados contra os direitos dos povos indígenas, pois poucos são os casos que, após retomarem o território tradicional, de lá são retirados se aplicada a legislação vigente.

A Justiça brasileira, de modo especial, por meio do Supremo Tribunal Federal, tem deferido liminares requeridas ora pela Funai, ora pelo Ministério Público Federal ${ }^{32}$, a fim de evitar tragédias a exemplo do assassinato do índio Terena, em 2013, chamado de Oziel Gabriel ${ }^{33}$, morto durante operação de reintegração de posse comandada pela Polícia Federal e apoiada pelo batalhão de Polícia Militar Estadual.

Os mais fortes sindicatos rurais de Mato Grosso do Sul, campeão na violência contra as comunidades tradicionais, contabilizaram o total de $140^{34}$ (cento e quarenta) fazendas retomadas pelos indígenas no Estado. Este é o fator que causa maior impacto, protagonizado pelos povos na busca da efetivação de seus direitos.

Esse fenômeno da resistência indígena materializada na retomada de territórios dos quais foram expulsos fez gerar, nos últimos anos, vários projetos de lei que visam modificar e/ou extinguirem direitos constantes no art. 231 da Carta Republicana.

31 "....] a resistência compreende todo comportamento de ruptura contra a ordem constituída, que ponha em crise o sistema pelo simples fato de produzir-se, como ocorre num tumulto, num motim, numa rebelião, numa insurreição, até o caso limite da revolução [...]" (BOBBIO, 2004, p. 61).

${ }^{32}$ Art. 129 da Constituição Federal: "São funções institucionais do Ministério Público: [...] V- defender judicialmente os direitos e interesses das populações indígenas".

${ }^{3}$ Disponível em: https://www.campograndenews.com.br/cidades/interior/morre-indio-ferido-em-confronto-com-a-policia-outros-tres-ficaram-feridos. Acesso em: 19 jun. 2019.

${ }^{34}$ Disponível em: https://www.midiamax.com.br/politica/2019/famasul-aponta-que-ms-tem-140-propriedades-em-conflitos-indigenas/. Acesso em: 19 jun. 2019. 
Primeiramente, tais atores apresentaram diversas proposições legislativas nas últimas décadas, e a 55a legislatura (2015-2019) é tida como a mais conservadora desde $1964^{35}$. Segundo levantamento do Conselho Indigenista Missionário:

[...] há, hoje, 33 proposições anti-indígenas em tramitação no Congresso e no Senado. Somadas às propostas apensadas por tratarem de temas semeIhantes, elas ultrapassam uma centena. Das 33 proposições anti-indígena apuradas, 17 buscam a alteração nos processos de demarcação de Terras Indígenas (TI) - oito sustam portarias declaratórias; seis transferem ao Congresso Nacional a competência de aprovar e gerir as demarcações das terras; as outras três correspondem a autorizar arrendamento em TI, impedir a desapropriação para demarcações de TI e estabelecer indenizações para invasores que ocupam TI após 2013. (CIMI, 2018a, p. 13).

O Conselho Indigenista Missionário indica ainda que, em 2017, foram identificadas 848 tramitações de projetos de lei desfavoráveis aos indígenas. Um levantamento da Agência Pública, com base nos dados do Cimi:

[...] identificou que os parlamentares ruralistas trabalham incansavelmente para fazer que as 33 propostas contra indígenas avancem. Isso fez com que as violências ruralistas sobre os direitos constitucionais das populações tradicionais atingissem 1.930 procedimentos legislativos em 2 anos - de 2015 a 2017. Esse número é maior que o de 20 anos, que chegou em 1.926 de 1995 até 2014 (CIMI, 2018b, p. 13-14).

Confirma-se o ambiente desfavorável aos indígenas, também denominado de tomada do Poder Legislativo, a partir de $1995^{36}$, um ano antes da entrada em vigor do Dec. 1.775/96, configurando o período da formação de bancadas contra os direitos indígenas para modificar a Constituição Federal, principalmente o art. 231.

A seguir, o montante financeiro empenhado nesses parlamentares, especificando aqui os atores de maior repercussão na causa indígena, iniciando pela atual ministra da Agricultura, Tereza Cristina (PSB/MS), cuja família37, inclusive, possui fazenda em terra indígena e a qual recebeu do agronegócio $\mathrm{R} \$ 2.689 .800,00$ (dois milhões e seiscentos e oitenta e nove mil e oitocentos reais); Luis Carlos Heinze

\footnotetext{
${ }^{35}$ Ver mais em Cimi, 2018a.

${ }^{36}$ Informação extraída com base em levantamento de proposições legislativas do Conselho Indigenista Missionário (CIMI, 2018a).

37 Encontrado em: https://www.campograndenews.com.br/politica/familia-da-ministra-tereza-cristina-tem-conflito-historico-com-indios-em-ms. Acesso em: 19 abr. 2019.
} 
(PP/RS), que recebeu $\mathrm{R} \$ 1.668 .200,00$ (um milhão e seiscentos e sessenta e oito mil e duzentos reais); Jerônimo Goergen (PP/RS), que recebeu $\mathrm{R} \$ 1.575 .800,00$ (um milhão e quinhentos e setenta e cinco mil e oitocentos reais). No Senado, temos Antonio Anastasia (PSDB/MG), recebendo R\$ 4.483.292,84 (quatro milhões e quatrocentos e oitenta e três mil e duzentos e noventa e dois reais e oitenta e quatro centavos); Simone Tebet (PMDB/MS), que recebeu $\mathrm{R} \$ 2.840 .000,00$ (dois milhões e oitocentos e quarenta mil reais); e, por fim, Katia Abreu (PDT/TO), que recebeu $\mathrm{R} \$ 2.485 .000,00$ (dois milhões e quatrocentos e oitenta e cinco mil reais). Isso na última campanha eleitoral (CIMI, 2018, p. 36).

Dentro do Poder Legislativo, houve a identificação de alguns instrumentos como sendo as principais pautas dos setores desfavoráveis aos indígenas, a fim de brecar a demarcação de Terras Indígenas e, com ela, todos os direitos indígenas arduamente conquistados, entre eles: PEC 215 38 : visa transferir ao Congresso Nacional a competência para homologar as demarcações das terras tradicionalmente ocupadas por comunidades indígenas, além de ratificar demarcações já homologadas; PLP 227/2012 39 : visa regulamentar o § 60 do art. 231, da CF de 1988, definindo os bens de relevante interesse da União para fins de demarcação de $\mathrm{TI}$, tornando qualquer medida desenvolvimentista de relevante interesse da União; e o PLP 227/2012, o qual foi pensado ao PLP 260/9040, que dispõe sobre a exploração das riquezas materiais do solo, dos rios e dos lagos em Terra Indígena.

\subsection{Poder Judiciário}

O Poder Judiciário é disciplinado em nossa Constituição do art. 92 ao 126, tendo como função compor conflitos de interesse em cada caso concreto; dessa

38 PEC 215/00 teve a maior impulsão nos últimos tempos, sendo somente barrada pelo movimento indígena no fim de 2015, nos últimos minutos do encerramento da legislatura, na Comissão de Constituição e Justiça, fazendo com que ela ficasse para segundo plano. Encontrado em: https://www.camara.leg.br/proposicoesWeb/fichadetramitacao?idProposicao=14562 Acesso em: 19 abr. 2019.

39 Disponível em: https://www.camara.leg.br/proposicoesWeb/fichadetramitacao?idProposic ao=584494. Acesso em: 19 abr. 2019.

${ }^{40}$ Disponível em: https://www2.camara.leg.br/camaranoticias/noticias/MEIO-AMBIENTE/97323PROPOSTA-REGULAMENTA-A-OCUPACAO-DE-TERRAS-INDIGENAS.html. Acesso em: 21 jun. 2019. 
forma, é exercida a jurisdição, vindo a se realizar por meio do processo judicial (SILVA, 2005, p. 555).

A jurisdição é exercida pelo Supremo Tribunal Federal; Superior Tribunal de Justiça; os tribunais regionais federais e juízes federais; os tribunais e juízes do Trabalho; os tribunais e juízes eleitorais; os tribunais e juízes militares; os tribunais e juízes dos estados, do Distrito Federal e dos territórios.

Sob a ótica da demarcação de terras indígenas, conforme exposto no art. 109, XI, cabe aos juízes federais, originalmente, processar e julgar conflitos relativos à disputa sobre direitos indígenas; dessa forma, matérias em que se discutem direitos indígenas de forma coletiva, a exemplo de ações declaratórias de domínio, ações possessórias, anulatórias de domínio etc., que incidam sobre terra indígena demarcada, reivindicada ou em processo de demarcação, devem ser processadas pela Justiça Federal e, consequentemente, pelo Tribunal Regional Federal, conforme sua jurisdição. E, por fim, pelo Supremo Tribunal Federal, cabendo ao Superior Tribunal de Justiça tão somente averiguar irregularidades procedimentais, não adentrando ao mérito do processo, que cabe ao Supremo Tribunal Federal.

As matérias de competência do STF, que constam no art. 102, são classificadas por José Afonso da Silva em três grupos:

(1) As que lhe cabe processar e julgar originariamente, ou seja, como Juízo único e definitivo, e são as questões relacionadas no inc. I; (2) as que the incumbe julgar, em recurso ordinário, e são as indicadas no inc. II; (3) e, finalmente, as que lhe toca julgar, em recurso extraordinário, e são as causas decididas em única ou última instância, quando a decisão recorrida envolve umas das questões constitucionais referidas nas alíneas do inc. III. (SILVA, 2005, p. 559).

Cabe, por fim, quanto à Suprema Corte, em relação aos julgamentos de direitos indígenas, analisar a denominada "súmula vinculante" ${ }^{41}$, que são de competência do Supremo Tribunal Federal, conforme disposto no art. 103-A, veja:

Art. 103-A, CF88. O Supremo Tribunal Federal poderá, de ofício ou por provocação, mediante decisão de dois terços dos seus membros, após reiteradas decisões sobre matéria constitucional, aprovar súmula que, a partir de sua

\footnotetext{
${ }^{41}$ Para Nelson Nery Junior, a súmula é o conjunto das teses jurídicas reveladoras da jurisprudência dominante no tribunal e vem traduzida em forma de verbetes sintéticos numerados e editados (NERES JUNIOR, 2000, p. 86).
} 
publicação na imprensa oficial, terá efeito vinculante em relação aos demais órgãos do Poder Judiciário e à administração pública direta e indireta, nas esferas federal, estadual e municipal, bem como proceder à sua revisão ou cancelamento, na forma estabelecida em lei.

§ 1ㅇ A súmula terá por objetivo a validade, a interpretação e a eficácia de normas determinadas, acerca das quais haja controvérsia atual entre órgãos judiciários ou entre esses e a administração pública que acarrete grave insegurança jurídica e relevante multiplicação de processos sobre questão idêntica.

$\S 2$ 2 Sem prejuízo do que vier a ser estabelecido em lei, a aprovação, revisão ou cancelamento de súmula poderá ser provocada por aqueles que podem propor a ação direta de inconstitucionalidade.

§ 3으o ato administrativo ou decisão judicial que contrariar a súmula aplicável ou que indevidamente a aplicar, caberá reclamação ao Supremo Tribunal Federal que, julgando-a procedente, anulará o ato administrativo ou cassará a decisão judicial reclamada, e determinará que outra seja proferida com ou sem a aplicação da súmula, conforme o caso.

Portanto a Suprema Corte pode contribuir com aspectos interpretativos da Constituição Federal, tanto para garantir quanto para negar ou modular direitos.

Em 2009, quando do julgamento do caso Raposa Serra do Sol, criaram-se 19 condicionantes para finalizar a demarcação daquela terra e, entre elas, surgiu a interpretação restritiva dos direitos indígenas na Constituição Federal de 1988, o marco temporal. O marco temporal visa estabelecer um divisor dos direitos territoriais dos povos indígenas antes e após a Constituição de 1988.

Para o ministro relator da PET. 3.388, Ayres Britto,

a Constituição Federal trabalhou com data certa - a data da promulgação dela própria (5 de outubro de 1988) - como insubstituível referencial para o dado da ocupação de um determinado espaço geográfico por essa ou aquela etnia aborígene; ou seja, para o reconhecimento, aos índios, dos direitos originários sobre as terras que tradicionalmente ocupam. (STF, 2010, p. 235).

Esse tema foi fixado no próprio julgamento como não sendo extensivo a outros casos, ou seja, não se vinculando a processos de matérias semelhantes; ainda assim, por ser de agrado dos setores, está sendo matéria de fundamentação de direito em quaisquer processos judiciais após seu surgimento, mesmo naqueles em que o julgamento de primeira instância ou em segunda ocorreu antes do seu surgimento, 
como no caso da Terra Indígena Buriti/MS (RE 997325, STF), que teve sua demarcação anulada com fundamento no marco temporal de ocupação pelo Tribunal Regional Federal da Terceira Região (TRF3), neste momento aguardando definição no STF.

O STF, considerado guardião da Constituição, afirmou, na Ementa do Acórdão, que julgou os embargos de declaração das aldeias indígenas e do Ministério Público Federal na Pet. 3.388, de forma que a decisão proferida não tem efeito vinculante e seus efeitos não se estendem, de forma automática, a outros processos em que se discutam matérias similares.

EMENTA: EMBARGOS DE DECLARAÇÃO. AÇÃO POPULAR. DEMARCAÇÃO DA TERRA INDÍGENA RAPOSA SERRA DO SOL. 1. Embargos de declaração opostos pelo autor, por assistentes, pelo Ministério Público, pelas comunidades indígenas, pelo Estado de Roraima e por terceiros. Recursos inadmitidos, desprovidos, ou parcialmente providos para fins de mero esclarecimento, sem efeitos modificativos. 2. Com o trânsito em julgado do acórdão embargado, todos os processos relacionados à Terra Indígena Raposa Serra do Sol deverão adotar as seguintes premissas como necessárias: (i) são válidos a Portaria/MJ no 534/2005 e o Decreto Presidencial de 15.04.2005, observadas as condições previstas no acórdão; e (ii) a caracterização da área como terra indígena, para os fins dos arts. 20, XI, e 231, da Constituição torna insubsistentes eventuais pretensões possessórias ou dominiais de particulares, salvo no tocante à indenização por benfeitorias derivadas da ocupação de boa-fé (CF/88, art. 231, § 60). 3. As chamadas condições ou condicionantes foram consideradas pressupostos para o reconhecimento da validade da demarcação efetuada. Não apenas por decorrerem, em essência, da própria Constituição, mas também pela necessidade de se explicitarem as diretrizes básicas para o exercício do usufruto indígena, de modo a solucionar de forma efetiva as graves controvérsias existentes na região. Nesse sentido, as condições integram o objeto do que foi decidido e fazem coisa julgada material. Isso significa que a sua incidência na Reserva da Raposa Serra do Sol não poderá ser objeto de questionamento em eventuais novos processos. 4. A decisão proferida em ação popular é desprovida de força vinculante, em sentido técnico. Nesses termos, os fundamentos adotados pela Corte não se estendem, de forma automática, a outros processos em que se discuta matéria similar. Sem prejuízo disso, o acórdão embargado ostenta a força moral e persuasiva de uma decisão da mais alta Corte do País, do que decorre um elevado ônus argumentativo nos casos em se cogite da superação de suas razões. (BRASIL, 2014).

Mesmo assim, vimos que a tese do marco temporal está sendo utilizada em todas as instâncias do Poder Judiciário; no Legislativo, por meio de projetos de leis como 
o Projeto de Lei n. 490/2007, que altera artigos da Lei n. 6.001/73; e no Executivo, por meio da Portaria 303/AGU/2012, seguida pelo Parecer Presidencial 001/2017.

\section{CONCLUSÃO}

Os direitos indígenas no Brasil não integram a agenda da maioria dos governantes, pois se contrapõem ao sistema econômico dominante, são tidos por eles, publicamente, como entraves ao desenvolvimento do país.

Com efeito, os índios sempre tiveram seus direitos violados, passando por um processo de genocídio histórico, marcado pelo desinteresse político para a efetivação dos direitos indígenas, entre eles, a demarcação de suas terras, pauta prioritária do movimento indígena em todas as regiões.

O Relatório de Violência do Conselho Indigenista Missionário (2018) mostra que 767 terras indígenas pendem de regularização, o que provoca uma acentuação na violência relacionada aos povos indígenas. E os números são alarmantes: nos anos de 2003 a 2017, foram 1.119 indígenas assassinados; deste total, 41,19\% são em Mato Grosso do Sul, estado conhecido internacionalmente pelo intenso conflito entre indígenas e fazendeiros. Dados do ano de 2017 indicam 68 indígenas assassinados.

Segundo dados do IBGE 2010, o Brasil tinha uma população de 3 milhões de indígenas no ano de 1500, restando apenas 70 mil em 1957; e, após a década de 1980, esse contingente populacional voltou a crescer, registrando-se, em 2010, uma população de 817,962 habitantes indígenas ${ }^{42}$.

Vários foram os períodos de expulsão e/ou remoção de comunidades indígenas de seus territórios, dando espaço à expansão da agricultura e pecuária no país, e Mato Grosso do Sul foi um dos estados que mais foi impactado por essa expansão desordenada, afetando os territórios indígenas por completo e contribuindo com disputas territoriais até a atualidade.

Várias são as consequências ocasionadas pela correlação de força política e econômica nas últimas décadas, que pressiona a garantia e efetivação dos direitos dos povos indígenas, especificamente, em relação às suas terras tradicionais.

${ }^{42}$ Disponível em: http://www.funai.gov.br/index.php/indios-no-brasil/quem-sao. Acesso em: 19 abr. 2019. 
Como já exposto neste trabalho, antes da Constituição Federal de 1988, o Estado somente garantia aos povos o espaço de ocupação permanente, não tendo respeitadas as demais garantias trazidas pelo caput do art. 231 da atual Constituição.

Por conta das mortes de diversos indígenas, há décadas sofridas pelos povos indígenas no Brasil, eles protagonizaram um forte processo de luta; entre as práticas, ressalta-se a retomada dos territórios de onde foram expulsos e a realização de grandes assembleias indígenas para reivindicação de direitos.

No período constituinte, os povos indígenas foram protagonistas de forte movimento que garantiu a promulgação do "Capítulo VIII dos Índios" na Constituição, de forma que foi alterada a política de Estado, rompendo com o paradigma da tutela indígena e da política integracionista, bem como dando lugar ao protagonismo e à autonomia das comunidades indígenas e ao direito às terras tradicionalmente ocupadas por eles, sua língua, seus costumes, crenças e tradições.

Assim, a questão indígena no país fica dividida em três períodos, a saber. O primeiro período de quase extinção que perpassa o momento da invasão portuguesa até a década de 1980, surgindo, assim, os primeiros movimentos indígenas pela mudança de paradigmas e defesa de direitos, alcançando-os com a promulgação da Constituição Federal de 1988; o segundo, da promulgação da Constituição Federal de 1988, regrando um verdadeiro estatuto jurídico da causa indígena, inovador constitucional protagonizado pelos povos indígenas que possibilitou uma série considerável de garantias e de efetivação de direitos aos povos, perdurando até a baixa do Dec. $1.775 / 96$, criado por pressão de setores que questionavam a legalidade das demarcações, estabelecendo um procedimento administrativo de demarcação de terras indígenas, antes não existente. Terceiro e contemporâneo, desde 1996, iniciou-se uma nova fase em relação aos direitos indígenas, que chamamos de "fase do declínio". Essa nova fase é caracterizada pelo protagonismo do Poder Legislativo (bancadas anti-indígenas), numa atuação forte e concentrada na busca incansável de mudança da legislação indigenista a fim de extinguir, modificar ou flexibilizar dispositivos constitucionais. Esses agentes vêm criando há décadas projetos de leis letais aos direitos indígenas, dando prioridade à mudança do texto constitucional sobre os direitos dos índios.

Pode-se conjecturar as estratégias desses setores no período do governo Lula e Dilma. Inicialmente, lotaram a pauta do Congresso com projetos de leis 
e emendas que, como já dito, visam modificar, flexibilizar ou extinguir direitos, que só não avançaram por força do movimento indígena. Após, com o Executivo, ocorre a paralisação nos processos de demarcação de terras indígenas em troca de colocar em pauta medidas prioritárias do governo e forçam, para isso, reduzir o orçamento da Funai, não haver abertura de concurso público para preenchimento de quadros, abandono político do órgão, entre outros fatores.

No entanto o Poder Legislativo não foi capaz de mudar o texto constitucional, e sua última tentativa foi frustrada com a não votação da PEC 215/00 em dezembro de 2015.

Só que, mesmo não cumprindo esse objetivo, a força dessas bancadas implantou dentro do Poder Executivo os instrumentos anti-indígenas, como a Portaria 303/2012, o Parecer 001/2017 e a MP 870/2019 reeditada pela MP $886 / 2019$, que, na prática, analisando a finalidade das propostas, dificultaram qualquer possibilidade de avanço em relação à efetivação de direitos indígenas a partir da demarcação de seus territórios.

Mesmo não sendo efetivado esse direito por dever do Estado em promover a demarcação, as comunidades indígenas, especificamente em Mato Grosso do Sul, estão na posse de várias propriedades rurais, continuando a exercer seu direito de resistência e, em processos autônomos, continuando a retomar seus territórios, parcial ou integralmente, obtidos por meio de suspensões de despejos de retomadas realizadas pelos índios.

Nesse ponto, já tendo visto que o Poder Legislativo e o Poder Executivo se encontram com pautas contrárias à efetivação dos direitos indígenas, resta então o Poder Judiciário, que vem concedendo, mesmo que de forma provisória, a manutenção da posse indígena.

Todavia está para ser julgado pela Suprema Corte o Recurso Extraordinário no 1017365, que discute o âmago da posse civilista (marco temporal) e da posse indígena (indigenato). Tal julgamento é interpretado pelo movimento indígena e aliados como a possibilidade de pôr fim à tese do marco temporal ou enterrar de vez a possibilidade de cumprimento da Carta Maior, com a vinculação da multicitada interpretação aplicada ao art. 231.

Com efeito, presencia-se um sistemático e voraz ataque do poder econômico e político às comunidades indígenas do país, em que todos os poderes do Estado estão 
influenciados tomados por medidas anti-indígena, e pode-se afirmar que qualquer iniciativa em prol da resolução do conflito passa a ser alvo imediato de algum projeto de lei ou emenda à Constituição Federal, a fim de embaraçar a sua efetivação.

\section{REFERÊNCIAS}

BOBBIO, Norberto. 1909 - A era dos direitos. Tradução de Carlos Nelson Coutinho. Rio de Janeiro: Elsevier, 2004.

BRASIL. Medida Provisória n. 870, de 10 de janeiro de 2019. Estabelece a organização básica dos órgãos da Presidência da República e dos Ministérios. Brasília-DF, 2019a. Disponível em: http://www.planalto.gov.br/ccivil_03/_ato2019-2022/2019/Mpv/mpv870. htm. Acesso em: 6 out. 2020.

BRASIL. Medida Provisória n. 886, de 2019. Altera a Lei n. 13.844, de 18 junho de 2019, a Lei n. 8.171, de 17 de janeiro de 1991, a Lei n. 12.897, de 18 de dezembro de 2013, a Lei n. 9.613, de 3 de março de 1998, e a Lei n. 13.334, de 13 de setembro de 2016, para dispor sobre a organização básica dos órgãos da Presidência da República e dos Ministérios. Brasília-DF, 2019b. Disponível em: https://www.congressonacional.leg.br/ materias/medidas-provisorias/-/mpv/137363; Acesso em: 6 out. 2020.

BRASIL. Supremo Tribunal Federal. Pet n. 3.388. Embargos de declaração. Ação popular. Demarcação da terra indígena Raposa Serra do Sol. Relator: Min. Roberto Barroso. Brasília-DF, 2014. Disponível em: http://redir.stf.jus.br/paginadorpub/paginador. jsp?docTP=TP\&doclD=5214423. Acesso em: 6 out. 2020.

BRASIL. Advocacia-Geral da União. Portaria n. 303, de 16 de julho de 2012. Dispõe sobre as salvaguardas institucionais às terras indígenas conforme entendimento fixado pelo Supremo Tribunal Federal na Petição 3.388 RR. Brasília-DF: 2012. Disponível em: http:// www4.planalto.gov.br/consea/comunicacao/artigos/2012/portaria-agu-303-advocaciae-ilegalidade-anti-indio. Acesso em: 6 out. 2020.

BRASIL. Advocacia-Geral da União. Portaria n. 839, de 18 de junho de 2010. Disciplina e estabelece critérios para a atuação dos órgãos da Procuradoria-Geral Federal na defesa de direitos indígenas. Brasília-DF, 2010. Disponível em: https://www.legisweb.com.br/ legislacao/?id=227561. Acesso em: 6 out. 2020.

BRASIL. Decreto n. 1.775, de 8 de janeiro de 1996. Dispõe sobre o procedimento administrativo de demarcação das terras indígenas e dá outras providências. Brasília-DF, 1996. Disponível em: http://www.planalto.gov.br/ccivil_03/decreto/d1775.htm. Acesso em: 6 out. 2020. 
Direitos constitucionais e povos indígenas: apontamentos sobre a disputa pela efetivação do direito fundamental às suas terras tradicionais

BRASIL. Constituição Federal de 1988. Brasília-DF, 1988. Disponível em http://www. planalto.gov.br/ccivil_03/constituicao/constituicao.htm. Acesso em: 13 nov. 2019.

CONSELHO INDIGENISTA MISSIONÁRIO. Congresso Anti-Indígena: os parlamentares que mais atuaram contra os direitos dos povos indígenas. Organização de Guilherme Cavalli. Brasília, DF: Cimi, 2018a.

CONSELHO INDIGENISTA MISSIONÁRIO. Relatório: Violência contra os Povos Indígenas no Brasil - dados de 2017. Organização de Lúcia Helena Rangel. Brasília, DF: Cimi, 2018b.

DUPRAT, Débora. A Convenção 169 da OIT e o direito à consulta prévia, livre e informada. Culturas Jurídicas, Niterói, v. 1, n. 1, p. 51-72, 2014.

ELOY AMADO, Luiz Henrique. Pokéexa ûti o território indígena como direito fundamental para o etnodesenvolvimento local. 2014. 125 f. Dissertação (Mestrado em Desenvolvimento Local) - Universidade Católica Dom Bosco, Campo Grande, MS, 2014.

MENDES JÚNIOR, João. Os indígenas do Brasil, seus direitos individuais e políticos. São Paulo: Typ. Hennies Irmãos, 1912.

NERY JUNIOR, Nelson. Princípios fundamentais: teoria geral dos recursos. 5. ed. São Paulo: Revista dos Tribunais, 2000.

PEREIRA, Levi M. Imagens Kaiowá do sistema social e seu entorno. Tese (Doutorado em Antropologia) - Universidade de São Paulo, São Paulo, SP, 2004.

SILVA, José Afonso. Parecer sobre Marco Temporal e Renitente Esbulho. São Paulo, 2016. Disponível em: http://www.mpf.mp.br/atuacao-tematica/ccr6/documentos-epublicacoes/artigos/docs_artigos/jose-afonso-da-silva-parecer-maio-2016-1.pdf. Acesso em: 17 jun. 2019.

SILVA, José Afonso. Curso de Direito Constitucional Positivo. 25. ed. revisada e atualizada nos termos da Reforma Constitucional, emenda constitucional n. 48, de 10/08/2005. São Paulo: Malheiros Editores, 2005.

SUPREMO TRIBUNAL FEDERAL. Ação Popular, PET. 3388. Brasília, DF, 2010.

\section{Sobre os autores:}

Antônio Hilário Aguilera Urquiza: Doutor em Antropologia. Professor adjunto da Universidade Federal de Mato Grosso do Sul (UFMS). Professor do Programa de Pós-Graduação em Antropologia da Universidade Federal da Grande Dourados (UFGD) 
e da Pós-Graduação em Educação da Universidade Católica Dom Bosco (UCDB). E-mail: hilarioaguilera@gmail.com, Orcid: http://orcid.org/0000-0002-3375-8630 Anderson Santos: Mestrando em Direito (área de concentração: Direitos Humanos) no Programa de Pós-Graduação em Direito da Universidade Federal de Mato Grosso do Sul (UFMS). Advogado do Conselho Indigenista Missionário (Cimi). E-mail: adv.andersonsantos@gmail.com, Orcid: http://orcid.org/0000-0003-1649-3797

Recebido em 30 de janeiro de 2020.

Aprovado para publicação em 10 de junho de 2020. 